\title{
Association of FURIN and ZPRI polymorphisms with metabolic syndrome
}

\author{
CHIKARA UEYAMA ${ }^{1}$, HIDEKI HORIBE ${ }^{1}$, YUICHIRO YAMASE ${ }^{1}$, TETSUO FUJIMAKI ${ }^{2}$, \\ MITSUTOSHI OGURI ${ }^{3}$, KIMIHIKO KATO ${ }^{4}$, MASAZUMI ARAI ${ }^{5}$, SACHIRO WATANABE ${ }^{5}$, \\ TOYOAKI MUROHARA $^{6}$ and YOSHIJI YAMADA ${ }^{7}$
}

\begin{abstract}
${ }^{1}$ Department of Cardiovascular Medicine, Gifu Prefectural Tajimi Hospital, Tajimi, Gifu 507-8522; ${ }^{2}$ Department of Cardiovascular Medicine, Inabe General Hospital, Inabe, Mie 511-0428; ${ }^{3}$ Department of Cardiology, Japanese Red Cross Nagoya First Hospital, Nagoya, Aichi 453-8511; ${ }^{4}$ Department of Internal Medicine, Meitoh Hospital, Nagoya, Aichi 465-0025; ${ }^{5}$ Department of Cardiology, Gifu Prefectural General Medical Center, Gifu 500-8717; ${ }^{6}$ Department of Cardiology, Nagoya University Graduate School of Medicine, Nagoya, Aichi 466-8550; ${ }^{7}$ Department of Human Functional Genomics, Life Science Research Center, Mie University, Tsu, Mie 514-8507, Japan
\end{abstract}

Received April 3, 2015; Accepted June 8, 2015

DOI: $10.3892 /$ br.2015.484

\begin{abstract}
Although genome-wide association studies (GWASs) have identified various genes and loci in predisposition to metabolic syndrome (MetS) or each component of this condition, the genetic basis of MetS in individuals remains to be identified definitively. The aim of the present study was to examine the possible association of MetS in individuals with 29 polymorphisms that were previously identified as susceptibility loci for coronary artery disease or myocardial infarction by meta-analyses of GWASs. The study population comprised 1,822 subjects with MetS and 1,096 controls. Subjects with MetS had $\geq 3$ of the 5 components of the diagnostic criteria for MetS, whereas control individuals had $0-1$ of the 5 components. The genotypes for the 29 polymorphisms were determined by the multiplex bead-based Luminex assay. Comparisons of allele frequencies by the $\chi^{2}$ test revealed that $\mathrm{rs} 17514846(\mathrm{~A} \rightarrow \mathrm{C})$ of the furin (paired basic amino acid-cleaving enzyme) gene (FURIN; $\mathrm{P}=0.0006)$, rs964184 $(\mathrm{C} \rightarrow \mathrm{G})$ of the ZPR1 zinc finger gene $(Z P R 1 ; \mathrm{P}=0.0078)$ and $\mathrm{rs} 599839(\mathrm{G} \rightarrow \mathrm{A})$ of the proline/serine-rich coiled-coil 1 gene $(\mathrm{P}=0.0486)$ were significantly $(\mathrm{P}<0.05)$ associated with the prevalence of MetS. Multivariable logistic regression analysis with adjustment for age, gender and smoking status revealed that rs17514846 of FURIN ( $\mathrm{P}=0.0016$; odds ratio, 0.76; dominant model) and rs964184 of ZPRI ( $\mathrm{P}=0.0164$; odds ratio, 1.21; dominant model) were significantly associated with MetS. The minor $A$ allele of rs17514846 of FURIN was significantly associated with a decrease in the serum concentration of triglycerides
\end{abstract}

Correspondence to: Professor Yoshiji Yamada, Department of Human Functional Genomics, Life Science Research Center, Mie University, 1577 Kurima-machiya, Tsu, Mie 514-8507, Japan

E-mail: yamada@gene.mie-u.ac.jp

Key words: metabolic syndrome, dyslipidemia, diabetes mellitus, genetics, polymorphism
$(\mathrm{P}=0.0293)$ and to an increase in the serum concentration of high-density lipoprotein (HDL) cholesterol $(\mathrm{P}=0.0460)$. The minor $G$ allele of rs964184 of ZPRI was significantly associated with increases in the serum concentration of triglycerides $\left(\mathrm{P}=6.2 \times 10^{-9}\right)$ and fasting plasma glucose level $(\mathrm{P}=0.0028)$ and to a decrease in the serum concentration of HDL cholesterol $(\mathrm{P}=0.0105)$. FURIN and ZPRI may thus be susceptibility loci for MetS.

\section{Introduction}

Metabolic syndrome (MetS) is an escalating public health problem worldwide, as this syndrome is an important risk factor for cardiovascular disease and diabetes mellitus (1). MetS is defined by a clustering of abdominal obesity, an increased serum concentration of triglycerides, a decreased serum concentration of high-density lipoprotein (HDL) cholesterol, high blood pressure and an increased fasting blood glucose level $(1,2)$. MetS confers a 5- or 2-fold increase in the risk of type 2 diabetes mellitus or cardiovascular disease, respectively, over the next 5-10 years (1). Individuals with MetS have a 2- to 4-fold increased risk of stroke, a 3 - to 4-fold risk of myocardial infarction and a 2-fold risk of mortality $(2,3)$. Therefore, the prevention and early diagnosis and treatment for MetS are important strategies for reducing the overall burden of cardiovascular disease. Given that genetic factors have been shown to contribute to individual susceptibility to MetS (4), the identification of genetic markers for disease risk is essential. Although recent genome-wide association studies (GWASs) have identified various genes in predisposition to MetS (5) or each component of MetS (6-8), the genetic basis of MetS as a composite phenotype remains to be identified definitively. Recent meta-analyses of GWASs also identified various genes and loci that confer susceptibility to coronary artery disease (CAD) or myocardial infarction in Caucasian populations $(9,10)$. As MetS is an important risk factor for CAD, we hypothesized that certain polymorphisms 
may contribute to the genetic susceptibility to CAD through affecting the susceptibility to MetS.

The aim of the present study was to examine the possible association of MetS in Japanese individuals with 29 single-nucleotide polymorphisms (SNPs) that were previously identified as susceptibility loci for CAD or myocardial infarction in Caucasian populations by the meta-analyses of GWASs.

\section{Subjects and methods}

Study population. The study comprised 2,918 Japanese individuals (1,822 subjects with MetS and 1,096 controls) who either visited the outpatient clinics or were admitted to the participating hospitals (Gifu Prefectural Tajimi Hospital, Tajimi; Gifu Prefectural General Medical Center, Gifu; Japanese Red Cross Nagoya First Hospital, Nagoya; Inabe General Hospital, Inabe; Hirosaki University Hospital and Hirosaki Stroke Center, Hirosaki, Japan) between 2002 and 2012.

Diagnosis of MetS was based on a modified version of the definition proposed by the International Diabetes Federation Task Force on Epidemiology and Prevention; National Heart, Lung and Blood Institute; American Heart Association; World Heart Federation; International Atherosclerosis Society; and International Association for the Study of Obesity (1). In this modified version, which was also used in the West of Scotland Coronary Prevention Study (11) and the Women's Health Study (12), body mass index (BMI) replaces waist circumference. Given that cut-off values of waist circumferences in Japan remain controversial, BMI was used in the present study instead of waist circumference. On the basis of the recognition of BMI criteria for obesity in Japanese and other Asian populations (13), the cut-off point for obesity was set as a BMI of $\geq 25 \mathrm{~kg} / \mathrm{m}^{2}$. In the preliminary experiments of 1,211 men and 583 women, BMI was significantly correlated with waist circumferences for men $\left(r=0.79, P=2.8 \times 10^{-262}\right)$ and for women $\left(r=0.72, P=9.7 \times 10^{-95}\right)$. A cut-off value of $25 \mathrm{~kg} / \mathrm{m}^{2}$ for BMI corresponded to 88.3 or $88.4 \mathrm{~cm}$ of waist circumference in men or women, respectively. A total of 1,822 subjects with MetS therefore had $\geq 3$ of the following 5 components: i) A BMI of $\geq 25 \mathrm{~kg} / \mathrm{m}^{2}$; ii) a serum concentration of triglycerides $\geq 1.65 \mathrm{mmol} / 1(150 \mathrm{mg} / \mathrm{dl})$ or drug treatment for elevated triglycerides; iii) a serum concentration of HDL cholesterol $<1.04 \mathrm{mmol} / \mathrm{l}$ (40 $\mathrm{mg} / \mathrm{dl})$ for men or $<1.30 \mathrm{mmol} / 1(50 \mathrm{mg} / \mathrm{dl})$ for women, or drug treatment for reduced HDL cholesterol; iv) a systolic blood pressure of $\geq 130 \mathrm{mmHg}$ or diastolic blood pressure of $\geq 85 \mathrm{mmHg}$, or drug treatment for hypertension; and v) a fasting plasma glucose level of $\geq 5.50 \mathrm{mmol} / 1(100 \mathrm{mg} / \mathrm{dl})$ or drug treatment for elevated glucose. History of obesity, dyslipidemia, hypertension or diabetes mellitus was evaluated from a detailed questionnaire. The controls comprised a total of 1,096 individuals who had 0-1 of the 5 components of diagnostic criteria for MetS.

The study protocol complied with the Declaration of Helsinki and was approved by the Ethics Committees in each participating Hospital. Written informed consent was obtained from all the subjects.

Selection and genotyping of polymorphisms. The SNPs that were shown to be significantly associated with CAD or myocardial infarction in Caucasian populations were searched by the meta-analyses of GWASs $(9,10)$. These SNPs were
Table I. Characteristics of the 2,918 study subjects.

\begin{tabular}{|c|c|c|c|}
\hline Characteristics & $\begin{array}{l}\text { Metabolic } \\
\text { syndrome }\end{array}$ & Controls & P-value \\
\hline Subjects, no. & 1,822 & 1,096 & \\
\hline Age, years & $64.4 \pm 10.3$ & $63.4 \pm 11.7$ & 0.0415 \\
\hline Gender (m/f, \%) & $67.4 / 32.6$ & $57.9 / 42.1$ & $<0.0001$ \\
\hline $\mathrm{BMI}, \mathrm{kg} / \mathrm{m}^{2}$ & $25.5 \pm 3.6$ & $21.8 \pm 2.3$ & $<0.0001$ \\
\hline $\begin{array}{l}\text { Current or former } \\
\text { smoker, } \%\end{array}$ & 30.9 & 24.1 & $<0.0001$ \\
\hline Dyslipidemia, \% & 61.3 & 36.0 & $<0.0001$ \\
\hline Diabetes mellitus, $\%$ & 57.7 & 15.7 & $<0.0001$ \\
\hline Hypertension, \% & 83.0 & 43.9 & $<0.0001$ \\
\hline $\begin{array}{l}\text { Systolic blood } \\
\text { pressure, } \mathrm{mmHg}\end{array}$ & $151 \pm 25$ & $129 \pm 23$ & $<0.0001$ \\
\hline $\begin{array}{l}\text { Diastolic blood } \\
\text { pressure, } \mathrm{mmHg}\end{array}$ & $81 \pm 16$ & $72 \pm 14$ & $<0.0001$ \\
\hline $\begin{array}{l}\text { Serum total } \\
\text { cholesterol, mmol/1 }\end{array}$ & $5.30 \pm 1.15$ & $5.06 \pm 0.92$ & $<0.0001$ \\
\hline $\begin{array}{l}\text { Serum triglycerides, } \\
\mathrm{mmol} / \mathrm{l}\end{array}$ & $2.21 \pm 1.46$ & $1.04 \pm 0.45$ & $<0.0001$ \\
\hline $\begin{array}{l}\text { Serum HDL } \\
\text { cholesterol, mmol/1 }\end{array}$ & $1.12 \pm 0.29$ & $1.55 \pm 0.40$ & $<0.0001$ \\
\hline $\begin{array}{l}\text { Serum LDL } \\
\text { cholesterol, mmol/1 }\end{array}$ & $3.20 \pm 1.00$ & $3.01 \pm 0.83$ & $<0.0001$ \\
\hline $\begin{array}{l}\text { Fasting plasma } \\
\text { glucose, } \mathrm{mmol} / 1\end{array}$ & $8.15 \pm 3.64$ & $5.42 \pm 2.28$ & $<0.0001$ \\
\hline $\begin{array}{l}\text { Blood glycosylated } \\
\text { hemoglobin, \% }\end{array}$ & $7.10 \pm 1.79$ & $6.26 \pm 1.63$ & $<0.0001$ \\
\hline $\begin{array}{l}\text { Serum creatinine, } \\
\mu \mathrm{mol} / \mathrm{l}\end{array}$ & $94.4 \pm 114.1$ & $79.4 \pm 80.9$ & $<0.0001$ \\
\hline
\end{tabular}

Quantitative data are mean \pm standard deviation. Quantitative data are compared between two groups by the Mann-Whitney U test. HDL, high-density lipoprotein; LDL, low-density lipoprotein; BMI, body mass index; $m$, male; $f$, female.

examined with the SNP database (dbSNP, National Center for Biotechnology Information, Bethesda, MD, USA) to find SNPs with a minor allele frequency of $\geq 0.015$ in a Japanese population. Finally, 29 SNPs (14) were selected and the association with MetS was examined.

Venous blood $(7 \mathrm{ml})$ was collected into tubes containing $50 \mathrm{mmol} / 1$ ethylenediaminetetraacetic acid (disodium salt), the peripheral blood leukocytes were isolated and genomic DNA was extracted from these cells with a DNA extraction kit (Genomix; Talent, Trieste, Italy). Genotypes of SNPs were determined at G\&G Science (Fukushima, Japan) by a method that combines polymerase chain reaction and sequence-specific oligonucleotide probes with suspension array technology (Luminex Corporation, Austin, TX, USA), as described previously (14-17). Detailed genotyping methodology was also as described previously (18).

Statistical analysis. The $\chi^{2}$ test was used to compare categorical variables. Quantitative data were compared between 
Table II. Comparison of the genotype distributions and allele frequencies of rs17514846 of FURIN, rs964184 of ZPR1 or rs599839 of PSRC1 by the $\chi^{2}$ test between subjects with metabolic syndrome and controls.

\begin{tabular}{|c|c|c|c|c|c|c|}
\hline Gene & SNP & MetS, n (\%) & Controls, n (\%) & Call rate $(\%)$ & P-value, genotype & P-value, allele \\
\hline \multicolumn{7}{|l|}{ FURIN } \\
\hline \multirow[t]{3}{*}{ rs17514846 $(\mathrm{A} \rightarrow \mathrm{C})$} & $C C$ & $1,338(73.8)$ & $739(68.5)$ & 99.1 & $0.0027^{\mathrm{a}}$ & $0.0006^{\mathrm{a}}$ \\
\hline & $C A$ & $438(24.2)$ & $303(28.1)$ & & & \\
\hline & $A A$ & $37(2.0)$ & $37(3.4)$ & & & \\
\hline Hardy-Weinberg P & & 0.8689 & 0.3902 & & & \\
\hline \multicolumn{7}{|l|}{$Z P R 1$} \\
\hline \multirow[t]{3}{*}{ rs964184 $(\mathrm{C} \rightarrow \mathrm{G})$} & $C C$ & $932(51.2)$ & $610(55.9)$ & 99.8 & $0.0297^{\mathrm{a}}$ & $0.0078^{\mathrm{a}}$ \\
\hline & $C G$ & $738(40.5)$ & 409 (37.5) & & & \\
\hline & $G G$ & $151(8.3)$ & $72(6.6)$ & & & \\
\hline Hardy-Weinberg P & & 0.7731 & 0.7581 & & & \\
\hline \multicolumn{7}{|l|}{ PSRC1 } \\
\hline \multirow[t]{3}{*}{$\operatorname{rs} 599839(\mathrm{G} \rightarrow \mathrm{A})$} & $A A$ & $1,573(86.8)$ & $910(84.0)$ & 99.2 & 0.1229 & $0.0486^{\mathrm{a}}$ \\
\hline & $A G$ & $225(12.4)$ & $163(15.1)$ & & & \\
\hline & $G G$ & $15(0.8)$ & $10(0.9)$ & & & \\
\hline Hardy-Weinberg P & & 0.0302 & 0.3726 & & & \\
\hline
\end{tabular}

${ }^{\mathrm{a}} \mathrm{P}<0.05$. FURIN, furin (paired basic amino acid cleaving enzyme) gene; ZPR1, ZPR1 zinc finger gene; PSRC1, proline/serine-rich coiled-coil 1 gene; MetS, metabolic syndrome; SNP, single-nucleotide polymorphism; Hardy-Weinberg P, P-value for the Hardy-Weinberg equilibrium.

two groups by the Mann-Whitney U test, as data were not normally distributed $(\mathrm{P}<0.01$ by the Kolmogorov-Smirnov and Lilliefors test). Allele frequencies were estimated by the gene counting method and allele frequencies of each SNP were compared between subjects with MetS and controls by the $\chi^{2}$ test. Multivariate logistic regression analysis was performed with MetS as a dependent variable and independent variables, including age, gender ( 0 female; 1 male), BMI, smoking status (0 non-smoker; 1 current or former smoker) and each genotype; and the P-value, odds ratio and $95 \%$ confidence interval were calculated. Genotypes of each polymorphism were assessed according to dominant $(0$ wild-type homozygote; 1 heterozygote and variant homozygote), recessive (0 wild-type homozygote and heterozygote; 1 variant homozygote) and additive genetic models. Additive models comprised additive 1 (heterozygotes versus wild-type homozygotes) and additive 2 (variant homozygotes versus wild-type homozygotes) models, which were analyzed simultaneously with a single statistical model. $\mathrm{P}<0.05$ was considered to indicate a statistically significant difference. Statistical test was performed with JMP version 5.1 and JMP Genomics version 6.0 softwares (SAS Institute Inc., Cary, NC, USA).

\section{Results}

Study characteristics. Characteristics of the study subjects are shown in Table I. Age, the frequency of men, BMI, the prevalence of smoking, dyslipidemia, diabetes mellitus, hypertension as well as serum concentrations of creatinine were greater in subjects with MetS compared to the controls.
Identification of the SNPs associated with MetS prevalence. On the basis of comparisons of genotype distributions or allele frequencies by the $\chi^{2}$ test, 3 SNPs were significantly $(\mathrm{P}<0.05)$ associated with the prevalence of MetS (Table II). Genotype distributions and allele frequencies of rs17514846 $(\mathrm{A} \rightarrow \mathrm{C})$ of the furin (paired basic amino acid cleaving enzyme) gene $(F U R I N)$ and $\mathrm{rs} 964184(\mathrm{C} \rightarrow \mathrm{G})$ of the ZPR1 zinc finger gene $(Z P R l)$ were significantly associated with the prevalence of MetS. Allele frequencies of $\operatorname{rs599839}(\mathrm{G} \rightarrow \mathrm{A})$ of the proline/serine-rich coiled-coil 1 gene were also significantly associated with MetS. Genotype distributions of 3 SNPs were in Hardy-Weinberg equilibrium ( $\mathrm{P}>0.05)$ among control individuals. These SNPs were further examined by multivariable logistic regression analysis with adjustment for covariates.

Multivariable logistic regression analysis with adjustment for age, gender and smoking status revealed that rs17514846 of FURIN (dominant, recessive and additive 1 and 2 models) was significantly $(\mathrm{P}<0.05)$ associated with MetS with the minor $A$ allele being protective against this condition (Table III). Similar analysis revealed that rs964184 of ZPR1 (dominant and additive 2 models) was significantly associated with MetS with the minor $G$ allele representing a risk factor for this condition.

Finally, the associations of rs17514846 of FURIN or rs964184 of ZPR1 to the components of MetS were examined, including BMI, systolic and diastolic blood pressure, serum concentrations of triglycerides and HDL cholesterol and fasting plasma glucose level in all the subjects (Table IV). The rs17514846 of FURIN was significantly $(\mathrm{P}<0.05)$ associated with serum concentrations of triglycerides (dominant and recessive models) and HDL cholesterol (dominant model) with the minor $A$ allele being associated with the decreased 
Table III. Multivariable logistic regression analysis of the polymorphisms associated with metabolic syndrome.

\begin{tabular}{|c|c|c|c|c|c|c|c|c|}
\hline \multirow[b]{2}{*}{ Gene polymorphism } & \multicolumn{2}{|r|}{ Dominant } & \multicolumn{2}{|c|}{ Recessive } & \multicolumn{2}{|c|}{ Additive 1} & \multicolumn{2}{|c|}{ Additive 2} \\
\hline & P-value & OR $(95 \% \mathrm{CI})$ & P-value & OR $(95 \% \mathrm{CI})$ & P-value & OR $(95 \% \mathrm{CI})$ & P-value & OR $(95 \% \mathrm{CI})$ \\
\hline \multicolumn{9}{|l|}{ FURIN } \\
\hline rs17514846 $(\mathrm{A} \rightarrow \mathrm{C})$ & $0.0016^{\mathrm{a}}$ & $0.76(0.65-0.90)$ & $0.0157^{\mathrm{a}}$ & $0.56(0.35-0.90)$ & $0.0089^{\mathrm{a}}$ & $0.79(0.67-0.94)$ & $0.0077^{\mathrm{a}}$ & $0.53(0.33-0.85)$ \\
\hline \multicolumn{9}{|l|}{ ZPRl } \\
\hline rs964184 $(\mathrm{C} \rightarrow \mathrm{G})$ & $0.0164^{\mathrm{a}}$ & $1.21(1.03-1.40)$ & 0.0706 & $1.31(0.98-1.77)$ & 0.0528 & $1.17(1.00-1.37)$ & $0.0280^{\mathrm{a}}$ & $1.40(1.04-1.91)$ \\
\hline \multicolumn{9}{|l|}{ PSRC1 } \\
\hline rs599839 $(\mathrm{G} \rightarrow \mathrm{A})$ & 0.0740 & $0.82(0.66-1.02)$ & 0.8474 & $0.92(0.41-2.14)$ & 0.0734 & $0.82(0.66-1.02)$ & 0.7951 & $0.90(0.40-2.09)$ \\
\hline
\end{tabular}

${ }^{a} \mathrm{P}<0.05$. Multivariable logistic regression analysis was performed with adjustment for age, gender and smoking status. FURIN, furin (paired basic amino acid cleaving enzyme) gene; ZPR1, ZPR1 zinc finger gene; PSRC1, proline/serine-rich coiled-coil 1 gene; OR, odds ratio; CI, confidence interval.

Table IV. Comparison of each metabolic syndrome component between two groups (dominant or recessive model) of the rs1751486 or rs964184 polymorphisms.

\begin{tabular}{|c|c|c|c|c|c|}
\hline \multirow[b]{2}{*}{ Characteristics } & & \multirow[b]{2}{*}{ Genotype } & & \multicolumn{2}{|c|}{ P-value } \\
\hline & & & & Dominant $^{\mathrm{a}}$ & Recessive $^{\mathrm{a}}$ \\
\hline FURIN (rs1751486) & $C C$ & $C A$ & $A A$ & & \\
\hline Body mass index, $\mathrm{kg} / \mathrm{m}^{2}$ & $24.2 \pm 3.6$ & $24.0 \pm 3.7$ & $23.8 \pm 4.1$ & 0.0559 & 0.2975 \\
\hline Systolic blood pressure, $\mathrm{mmHg}$ & $144 \pm 27$ & $142 \pm 27$ & $139 \pm 27$ & 0.1149 & 0.2222 \\
\hline Diastolic blood pressure, $\mathrm{mmHg}$ & $78 \pm 16$ & $78 \pm 15$ & $76 \pm 16$ & 0.6812 & 0.2317 \\
\hline Serum triglycerides, $\mathrm{mmol} / \mathrm{l}$ & $1.80 \pm 1.35$ & $1.73 \pm 1.25$ & $1.43 \pm 0.75$ & $0.0293^{\mathrm{b}}$ & $0.0396^{\mathrm{b}}$ \\
\hline Serum HDL cholesterol, mmol/l & $1.27 \pm 0.39$ & $1.30 \pm 0.43$ & $1.31 \pm 0.35$ & $0.0460^{\mathrm{b}}$ & 0.3238 \\
\hline Fasting plasma glucose, mmol/l & $7.19 \pm 3.47$ & $7.05 \pm 3.55$ & $6.36 \pm 2.15$ & 0.0809 & 0.1570 \\
\hline ZPRI (rs964184) & $C C$ & $C G$ & $G G$ & & \\
\hline Body mass index, $\mathrm{kg} / \mathrm{m}^{2}$ & $24.1 \pm 3.5$ & $24.1 \pm 3.7$ & $24.4 \pm 3.6$ & 0.9126 & 0.1129 \\
\hline Systolic blood pressure, $\mathrm{mmHg}$ & $144 \pm 27$ & $144 \pm 26$ & $143 \pm 27$ & 0.8475 & 0.7523 \\
\hline Diastolic blood pressure, $\mathrm{mmHg}$ & $78 \pm 15$ & $79 \pm 16$ & $78 \pm 15$ & 0.9351 & 0.4987 \\
\hline Serum triglycerides, $\mathrm{mmol} / \mathrm{l}$ & $1.65 \pm 1.21$ & $1.84 \pm 1.38$ & $2.21 \pm 1.52$ & $6.2 \times 10^{-9 b}$ & $1.4 \times 10^{-6 \mathrm{~b}}$ \\
\hline Serum HDL cholesterol, mmol/l & $1.30 \pm 0.40$ & $1.26 \pm 0.39$ & $1.24 \pm 0.37$ & $0.0105^{\mathrm{b}}$ & 0.1043 \\
\hline Fasting plasma glucose, mmol/l & $6.94 \pm 3.27$ & $7.25 \pm 3.51$ & $7.75 \pm 4.31$ & $0.0028^{\mathrm{b}}$ & 0.0530 \\
\hline
\end{tabular}

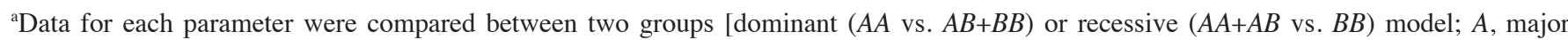
allele; $B$, minor allele] by the Mann-Whitney U test. ${ }^{b} \mathrm{P}<0.05$. HDL, high-density lipoprotein; $F U R I N$, furin (paired basic amino acid cleaving enzyme) gene; ZPR1, ZPR1 zinc finger gene.

serum triglycerides and to the increased serum HDL cholesterol. The rs964184 of ZPR1 was significantly associated with serum concentrations of triglycerides (dominant and recessive models), HDL cholesterol (dominant model) and fasting plasma glucose level (dominant model). The minor $G$ allele of this SNP was associated with the increased serum triglycerides and fasting plasma glucose level and to the decreased serum HDL cholesterol.

\section{Discussion}

The present study examined the associations of 29 SNPs identified by the meta-analyses of GWASs for CAD in Caucasian populations $(9,10)$ to MetS in 2,918 Japanese individuals. The study showed that rs17514846 of FURIN and rs964184 of ZPRI were significantly associated with the prevalence of MetS, with the minor $A$ allele of rs17514846 being protective against and the minor $G$ allele of rs964184 representing a risk factor for this condition.

FURIN is an enzyme that belongs to the proprotein convertase subtilisin/kexin (PCSK) family, a type 1 membrane-bound protease that processes latent precursor proteins into their biologically active products (19) and it is expressed in numerous tissues, including neuroendocrine organs, liver, gut and brain (Entrez Gene, NCBI). The expression of FURIN was enhanced by growth factors, such as 
transforming growth factor $\beta 1$ and interleukin $12(20,21)$, and elevated FURIN levels were shown to promote the metastatic activity of cancer, atherosclerosis and the pseudomonas infection of cystic fibrosis (22-25). A previous study (26) showed that FURIN may play a pivotal role in the renin-angiotensin system in that this enzyme participates in the rennin receptor processing and in maintaining the sodium-electrolyte balance. Several SNPs of FURIN were thus associated with hypertension (27-29). Several PCSKs, including FURIN, are shown to cleave endothelial and lipoprotein lipases, leading to their inactivation (30,31). Endothelial lipase regulates HDL metabolism through its cleavage into free fatty acids and triglycerides (30), whereas lipoprotein lipase plays a critical role in metabolism of triglycerides by hydrolyzing triglyceride-rich lipoprotein to free fatty acids (32). These observations suggest that FURIN plays an important role in lipid metabolism through the cleavage of endothelial and lipoprotein lipases. The present study has shown that rs17514846 of FURIN was significantly associated with MetS with the minor $A$ allele correlating to the decreased serum triglycerides and the increased serum HDL cholesterol. The association of rs17514846 of FURIN with MetS may be attributable to the effects of this SNP on metabolism of triglycerides and HDL cholesterol, although the underlying molecular mechanism remains to be elucidated.

ZPR1 is a regulatory protein for cell proliferation and signal transduction and may have multiple physiological functions $(33,34)$. Deficiency of ZPR1 is suggested to cause neurodegenerative disorders such as spinal muscular atrophy $(35,36)$. The most relevant transcription factor that binds to the promoter region of ZPRI is peroxisome proliferator-activated receptor $\gamma$, which plays an important role in insulin sensitivity and obesity $(37,38)$. This promoter region is also bound by hepatocyte nuclear factor $4 \alpha$, which activates a variety of genes involved in glucose, fatty acid and cholesterol metabolism (39). The previous GWASs in various ethnic groups showed the association of rs964184 of ZPRl with serum concentrations of triglycerides, low-density lipoprotein cholesterol and HDL cholesterol (40-43). Our previous study showed that rs964184 of ZPRI was associated with hypertriglyceridemia in Japanese individuals (44). The rs964184 is located near the apolipoprotein A5-A4-C3-A1 (APOA5-A4-C3-A1) locus, which is associated with plasma triglycerides in diverse populations (45-49). Expression of APOA5 is an efficient regulator of plasma triglycerides by enhancing the catabolism of triglyceride-rich lipoprotein (50) and prohibiting the transportation of triglycerides (51). These observations suggest that the association of rs964184 of ZPRI with serum triglycerides and HDL cholesterol may be attributable to linkage disequilibrium with functional polymorphisms in APOA5 that influence lipid metabolism (52). The present study showed that the minor $G$ allele of rs964184 of $Z P R I$ was significantly associated with the increased serum triglycerides and decreased serum HDL cholesterol in Japanese individuals, consistent with the previous studies (40-44).

An increase in the serum concentration of triglycerides is an important risk factor for type 2 diabetes mellitus (53). Several studies suggested that polymorphisms of APOA5 may play an important role in the development of type 2 diabetes mellitus $(54,55)$. Our previous study showed that rs964184 of ZPRI was significantly associated with type 2 diabetes mellitus in Japanese individuals (56). In the present study, the $G$ allele of rs964184 was associated with the increased fasting plasma glucose level. These observations suggest that rs 964184 of ZPR1 may alter the metabolism of triglycerides, HDL cholesterol or glucose through the interaction with APOA5, leading to the development of MetS, although the molecular mechanism remains unclear.

There were several limitations in the present study: i) Given that the results were not replicated, validation of the findings is required in other independent subject panels or in other ethnic groups. ii) It is possible that rs17514846 of FURIN or rs964184 of ZPRI is in linkage disequilibrium with other polymorphisms in the same gene or in other nearby genes that are responsible for the development of MetS. iii) The functional relevance of rs17514846 of FURIN or rs964184 of ZPRI to the pathogenesis of MetS remains unclear.

In conclusion, the present results suggest that FURIN and ZPRI may be susceptibility loci for MetS in Japanese individuals. Determination of genotypes for these polymorphisms may prove informative for assessment of the genetic risk for MetS in the Japanese population.

\section{Acknowledgements}

The present study was supported by a Collaborative Research grant from the Gifu Prefectural General Medical Center (no. H24-26 to Y.Y.) and a Grant-in-Aid for Scientific Research from the Ministry of Education, Culture, Sports, Science and Technology of Japan (no. 24590746 to Y.Y.).

\section{References}

1. Alberti KG, Eckel RH, Grundy SM, Zimmet PZ, Cleeman JI, Donato KA, Fruchart JC, James WP, Loria CM and Smith SC Jr; International Diabetes Federation Task Force on Epidemiology and Prevention; National Heart, Lung and Blood Institute; American Heart Association; World Heart Federation; International Atherosclerosis Society; International Association for the Study of Obesity: Harmonizing the metabolic syndrome: A joint interim statement of the International Diabetes Federation Task Force on Epidemiology and Prevention; National Heart, Lung and Blood Institute; American Heart Association; World Heart Federation; International Atherosclerosis Society; and International Association for the Study of Obesity. Circulation 120: 1640-1645, 2009.

2. Alberti KG,Zimmet P and Shaw J; IDF Epidemiology Task Force Consensus Group: The metabolic syndrome - a new worldwide definition. Lancet 366: 1059-1062, 2005.

3. Olijhoek JK, van der Graaf Y, Banga J-D, Algra A, Rabelink TJ and Visseren FL; SMART Study Group: The metabolic syndrome is associated with advanced vascular damage in patients with coronary heart disease, stroke, peripheral arterial disease or abdominal aortic aneurysm. Eur Heart J 25: 342-348, 2004.

4. Groop L: Genetics of the metabolic syndrome. Br J Nutr 83 (Suppl 1): S39-S48, 2000.

5. Park YM, Province MA, Gao X, Feitosa M, Wu J, Ma D, Rao D and Kraja AT: Longitudinal trends in the association of metabolic syndrome with $550 \mathrm{k}$ single-nucleotide polymorphisms in the Framingham Heart Study. BMC Proc 3 (Suppl 7): S116, 2009.

6. Zeggini E, Scott LJ, Saxena R, Voight BF, Marchini JL, Hu T, de Bakker PI, Abecasis GR, Almgren P, Andersen G, et al; Wellcome Trust Case Control Consortium: Meta-analysis of genome-wide association data and large-scale replication identifies additional susceptibility loci for type 2 diabetes. Nat Genet 40: 638-645, 2008.

7. Kooner JS, Chambers JC, Aguilar-Salinas CA, Hinds DA, Hyde CL, Warnes GR, Gómez Pérez FJ, Frazer KA, Elliott P, Scott J, et al: Genome-wide scan identifies variation in MLXIPL associated with plasma triglycerides. Nat Genet 40: 149-151, 2008. 
8. Frayling TM, Timpson NJ, Weedon MN, Zeggini E, Freathy RM, Lindgren CM, Perry JR, Elliott KS, Lango H, Rayner NW, et al: A common variant in the FTO gene is associated with body mass index and predisposes to childhood and adult obesity. Science 316: 889-894, 2007.

9. Schunkert H, König IR, Kathiresan S, Reilly MP, Assimes TL, Holm H, Preuss M, Stewart AF, Barbalic M, Gieger C, et al; Cardiogenics; CARDIoGRAM Consortium: Large-scale association analysis identifies 13 new susceptibility loci for coronary artery disease. Nat Genet 43: 333-338, 2011.

10. Deloukas P, Kanoni S, Willenborg C, Farrall M, Assimes TL, Thompson JR, Ingelsson E, Saleheen D, Erdmann J, Goldstein BA, et al; CARDIoGRAMplusC4D Consortium; DIAGRAM Consortium; CARDIOGENICS Consortium; MuTHER Consortium; Wellcome Trust Case Control Consortium: Large-scale association analysis identifies new risk loci for coronary artery disease. Nat Genet 45: 25-33, 2013.

11. Sattar N, Gaw A, Scherbakova O, Ford I, O'Reilly DS, Haffner SM, Isles C, Macfarlane PW, Packard CJ, Cobbe SM, et al: Metabolic syndrome with and without C-reactive protein as a predictor of coronary heart disease and diabetes in the West of Scotland Coronary Prevention Study. Circulation 108: 414-419, 2003.

12. Ridker PM, Buring JE, Cook NR and Rifai N: C-reactive protein, the metabolic syndrome, and risk of incident cardiovascular events: An 8-year follow-up of 14,719 initially healthy American women. Circulation 107: 391-397, 2003.

13. Kanazawa M, Yoshiike N, Osaka T, Numba Y, Zimmet P and Inoue S: Criteria and classification of obesity in Japan and Asia-Oceania. Asia Pac J Clin Nutr 11 (Suppl 8): S732-S737, 2002.

14. Matsuoka R, Abe S, Tokoro F, Arai M, Noda T, Watanabe S, Horibe H, Fujimaki T, Oguri M, Kato K, et al: Association of six genetic variants with myocardial infarction. Int J Mol Med 35: 1451-1459, 2015

15. Yamada Y, Fuku N, Tanaka M, Aoyagi Y, Sawabe M, Metoki N, Yoshida H, Satoh K, Kato K, Watanabe S, et al: Identification of CELSR 1 as a susceptibility gene for ischemic stroke in Japanese individuals by a genome-wide association study. Atherosclerosis 207: 144-149, 2009.

16. Yamada Y, Nishida T, Ichihara S, Sawabe M, Fuku N, Nishigaki Y, Aoyagi Y, Tanaka M, Fujiwara Y, Yoshida H, et al: Association of a polymorphism of BTN2A1 with myocardial infarction in East Asian populations. Atherosclerosis 215: 145-152, 2011.

17. Yamada Y, Nishida T, Ichihara S, Kato K, Fujimaki T, Oguri M, Horibe H, Yoshida T, Watanabe S, Satoh K, et al: Identification of chromosome $3 \mathrm{q} 28$ and ALPK1 as susceptibility loci for chronic kidney disease in Japanese individuals by a genome-wide association study. J Med Genet 50: 410-418, 2013.

18. Itoh Y, Mizuki N, Shimada T, Azuma F, Itakura M, Kashiwase K, Kikkawa E, Kulski JK, Satake M and Inoko H: High-throughput DNA typing of HLA-A, -B, -C and -DRB1 loci by a PCR-SSOP-Luminex method in the Japanese population. Immunogenetics 57: 717-729, 2005.

19. Remacle AG, Shiryaev SA, Oh ES, Cieplak P, Srinivasan A, Wei G, Liddington RC, Ratnikov BI, Parent A, Desjardins R, et al: Substrate cleavage analysis of furin and related proprotein convertases. A comparative study. J Biol Chem 283: 20897-20906, 2008.

20. Blanchette F, Day R, Dong W, Laprise MH and Dubois CM: TGFbeta1 regulates gene expression of its own converting enzyme furin. J Clin Invest 99: 1974-1983, 1997.

21. Pesu M, Muul L, Kanno Y and O'Shea JJ: Proprotein convertase furin is preferentially expressed in T helper 1 cells and regulates interferon gamma. Blood 108: 983-985, 2006.

22. Turpeinen H, Raitoharju E, Oksanen A, Oksala N, Levula M, Lyytikäinen LP, Järvinen $\mathrm{O}$, Creemers JW, Kähönen $M$, Laaksonen R, et al: Proprotein convertases in human atherosclerotic plaques: The overexpression of FURIN and its substrate cytokines BAFF and APRIL. Atherosclerosis 219: 799-806, 2011

23. Turpeinen H, Ortutay $Z$ and Pesu M: Genetics of the first seven proprotein convertase enzymes in health and disease. Curr Genomics 14: 453-467, 2013

24. Bassi DE, Mahloogi H, Al-Saleem L, Lopez De Cicco R, Ridge JA and Klein-Szanto AJ: Elevated furin expression in aggressive human head and neck tumors and tumor cell lines. Mol Carcinog 31: 224-232, 2001

25. Ornatowski W, Poschet JF, Perkett E, Taylor-Cousar JL and Deretic V: Elevated furin levels in human cystic fibrosis cells result in hypersusceptibility to exotoxin A-induced cytotoxicity. J Clin Invest 117: 3489-3497, 2007.
26. Cousin C, Bracquart D, Contrepas A, Corvol P, Muller L and Nguyen G: Soluble form of the (pro)renin receptor generated by intracellular cleavage by furin is secreted in plasma. Hypertension 53: 1077-1082, 2009

27. Ehret GB, Munroe PB, Rice KM, Bochud M, Johnson AD, Chasman DI, Smith AV, Tobin MD, Verwoert GC, Hwang SJ, et al; CHARGE-HF consortium: Genetic variants in novel pathways influence blood pressure and cardiovascular disease risk. Nature 478: 103-109, 2011.

28. Li N, Luo W, Juhong Z, Yang J, Wang H, Zhou L and Chang J: Associations between genetic variations in the FURIN gene and hypertension. BMC Med Genet 11: 124, 2010.

29. Ganesh SK, Tragante V, Guo W, Guo Y, Lanktree MB, Smith EN, Johnson T, Castillo BA, Barnard J, Baumert J, et al; CARDIOGRAM, METASTROKE; LifeLines Cohort Study: Loci influencing blood pressure identified using a cardiovascular gene-centric array. Hum Mol Genet 22: 1663-1678, 2013.

30. Seidah NG, Khatib AM and Prat A: The proprotein convertases and their implication in sterol and/or lipid metabolism. Biol Chem 387: 871-877, 2006.

31. Choi S and Korstanje R: Proprotein convertases in high-density lipoprotein metabolism. Biomark Res 1: 27, 2013

32. Franssen R, Visser ME, Kuivenhoven JA, et al: Role of lipoprotein lipase in triglyceride metabolism: Potential therapeutic target. Future Lipidol 3: 385-397, 2008.

33. Galcheva-Gargova Z, Gangwani L, Konstantinov KN, Mikrut M, Theroux SJ, Enoch T and Davis RJ: The cytoplasmic zinc finger protein ZPR1 accumulates in the nucleolus of proliferating cells. Mol Biol Cell 9: 2963-2971, 1998.

34. Galcheva-Gargova Z, Konstantinov KN, Wu IH, Klier FG, Barrett T and Davis RJ: Binding of zinc finger protein ZPR1 to the epidermal growth factor receptor. Science 272: 1797-1802, 1996.

35. Gangwani L: Deficiency of the zinc finger protein ZPR1 causes defects in transcription and cell cycle progression. J Biol Chem 281: 40330-40340, 2006

36. Ahmad S, Wang Y, Shaik GM, Burghes AH and Gangwani L: The zinc finger protein ZPR1 is a potential modifier of spinal muscular atrophy. Hum Mol Genet 21: 2745-2758, 2012.

37. Mangelsdorf DJ, Thummel C, Beato M, Herrlich P, Schütz G, Umesono K, Blumberg B, Kastner P, Mark M, Chambon P, et al: The nuclear receptor superfamily: The second decade. Cell 83: $835-839,1995$.

38. Corton JC, Anderson SP and Stauber A: Central role of peroxisome proliferator-activated receptors in the actions of peroxisome proliferators. Annu Rev Pharmacol Toxicol 40: 491-518, 2000.

39. Sladek FM, Zhong WM, Lai E and Darnell JE Jr: Liver-enriched transcription factor HNF-4 is a novel member of the steroid hormone receptor superfamily. Genes Dev 4 (12B): 2353-2365, 1990.

40. Waterworth DM, Ricketts SL, Song K, Chen L, Zhao JH, Ripatti S, Aulchenko YS, Zhang W, Yuan X, Lim N, et al; Wellcome Trust Case Control Consortium: Genetic variants influencing circulating lipid levels and risk of coronary artery disease. Arterioscler Thromb Vasc Biol 30: 2264-2276, 2010.

41. Teslovich TM, Musunuru K, Smith AV, Edmondson AC, Stylianou IM, Koseki M, Pirruccello JP, Ripatti S, Chasman DI, Willer CJ, et al: Biological, clinical and population relevance of 95 loci for blood lipids. Nature 466: 707-713, 2010

42. Nakayama K, Yanagisawa Y, Ogawa A,Ishizuka Y, Munkhtulga L, Charupoonphol P, Supannnatas S, Kuartei S, Chimedregzen U, Koda Y, et al: High prevalence of an anti-hypertriglyceridemic variant of the MLXIPL gene in Central Asia. J Hum Genet 56: 828-833, 2011.

43. Kathiresan S, Willer CJ, Peloso GM, Demissie S, Musunuru K, Schadt EE, Kaplan L, Bennett D, Li Y, Tanaka T, et al: Common variants at 30 loci contribute to polygenic dyslipidemia. Nat Genet 41: 56-65, 2009

44. Abe S, Tokoro F, Matsuoka R, et al: Association of genetic variants with dyslipidemia. Mol Med Rep (In press).

45. Kathiresan S, Melander O, Guiducci C, Surti A, Burtt NP, Rieder MJ, Cooper GM, Roos C, Voight BF, Havulinna AS, et al: Six new loci associated with blood low-density lipoprotein cholesterol, high-density lipoprotein cholesterol or triglycerides in humans. Nat Genet 40: 189-197, 2008.

46. Willer CJ, Sanna S, Jackson AU, Scuteri A, Bonnycastle LL, Clarke R, Heath SC, Timpson NJ, Najjar SS, Stringham HM, et al: Newly identified loci that influence lipid concentrations and risk of coronary artery disease. Nat Genet 40: 161-169, 2008. 
47. Yan SK, Cheng XQ, Song YH, Xiao XH, Bi N and Chen BS: Apolipoprotein A5 gene polymorphism -1131T $\rightarrow$ C: Association with plasma lipids and type 2 diabetes mellitus with coronary heart disease in Chinese. Clin Chem Lab Med 43: 607-612, 2005.

48. Klos KL, Sing CF, Boerwinkle E, Hamon SC, Rea TJ, Clark A Fornage $\mathrm{M}$ and Hixson JE: Consistent effects of genes involved in reverse cholesterol transport on plasma lipid and apolipoprotein levels in CARDIA participants. Arterioscler Thromb Vasc Biol 26: 1828-1836, 2006.

49. Ken-Dror G, Goldbourt U and Dankner R: Different effects of apolipoprotein A5 SNPs and haplotypes on triglyceride concentration in three ethnic origins. J Hum Genet 55: 300-307, 2010.

50. Jakel H, Nowak M, Helleboid-Chapman A, Fruchart-Najib J and Fruchart JC: Is apolipoprotein A5 a novel regulator of triglyceride-rich lipoproteins? Ann Med 38: 2-10, 2006.

51. Garelnabi M, Lor K, Jin J, Chai F and Santanam N: The paradox of ApoA5 modulation of triglycerides: Evidence from clinical and basic research. Clin Biochem 46: 12-19, 2013.

52. O'Brien PJ, Alborn WE, Sloan JH, Ulmer M, Boodhoo A, Knierman MD, Schultze AE and Konrad RJ: The novel apolipoprotein A5 is present in human serum, is associated with VLDL, HDL and chylomicrons, and circulates at very low concentrations compared with other apolipoproteins. Clin Chem 51: 351-359, 2005 .
53. Bernstein RM, Davis BM, Olefsky JM and Reaven GM: Hepatic insulin responsiveness in patients with endogenous hypertriglyceridaemia. Diabetologia 14: 249-253, 1978

54. Talmud PJ, Cooper JA, Hattori H, Miller IP, Miller GJ and Humphries SE: The apolipoprotein A-V genotype and plasma apolipoprotein A-V and triglyceride levels: Prospective risk of type 2 diabetes. Results from the Northwick Park Heart Study II. Diabetologia 49: 2337-2340, 2006.

55. Sóter MO, Gomes KB, Fernandes AP, Carvalho M, Pinheiro PS, Bosco AA, Silva DD and Sousa MO: -1131 T $>C$ and SW19 polymorphisms in APOA5 gene and lipid levels in type 2 diabetic patients. Mol Biol Rep 39: 7541-7548, 2012.

56. Tokoro F, Matsuoka R, Abe S, Arai M, Noda T, Watanabe S, Horibe H, Fujimaki T, Oguri M, Kato K, et al: Association of a genetic variant of the ZPR1 zinc finger gene with type 2 diabetes mellitus. Biomed Rep 3: 88-92, 2015. 